\title{
Surveillance of canine visceral leishmaniasis in a disease-free area
}

\author{
Vigilância da leishmaniose visceral canina em área indene \\ Michele Salmon Frehse ${ }^{1}$; Haroldo Greca Júnior ${ }^{2}$; Leila Sabrina Ullmann²; Lucilene Granuzzio Camossi²; \\ Juliana G. Machado ${ }^{2}$; Hélio Langoni ${ }^{2}$; Alexander Welker Biondo ${ }^{1}$; Marcelo Beltrão Molento ${ }^{1 *}$ \\ ${ }^{1}$ Departamento de Medicina Veterinária, Universidade Federal do Paraná - UFPR \\ ${ }^{2}$ Departamento de Higiene Veterinária e Saúde Pública, Universidade Estadual Paulista - UNESP
}

Received September 21, 2009

Accepted November 4, 2009

\begin{abstract}
Leishmaniasis is an important re-emergent parasitosis worldwide, particularly in tropical countries. There are no reports of autochthonous disease in the State of Paraná, southern Brazil. No surveillance has been carried out in the most populated areas such as the city of Curitiba and its surroundings. The purpose of the present study was to determine the seroprevalence of visceral leishmaniasis in dogs at the Center for Zoonosis Control of São José dos Pinhais, Paraná, before euthanasia. Enzyme-linked immunosorbent assay (ELISA) and immunofluorescence antibody test (IFAT) were used to detect antibody levels against Leishmania sp. in dog sera. Imprints of the popliteal lymph nodes that were also randomly collected from 50 dogs with suspected clinical signs of visceral leishmaniasis, and evaluated under light microscopy for the detection of amastigote forms, were negative. A total of $364 \mathrm{dog}$ samples were tested. The results showed only one positive sample $(0.0027 \%)$ by ELISA test but negative by IFAT, however, the dog had no clinical signs. Random surveillance of dog populations from several districts of a metropolitan area may be a means of preventing Leishmania spreading. Based on our results, the city of Curitiba and its metropolitan area were considered at low risk for visceral leishmaniasis.
\end{abstract}

Keywords: Leishmania sp., ELISA, RIFI, dog, zoonoses.

\section{Resumo}

A leishmaniose é uma importante parasitose re-emergente observada no mundo, particularmente em países tropicais. Não há ainda relatos de casos autóctones no estado do Paraná. Não há até o momento referência de vigilância no reservatório canino, tais como Curitiba e regiáo metropolitana do estado. O objetivo do estudo foi determinar a soroprevalência da leishmaniose visceral em cáes entregues ao Centro de Controle de Zoonoses de São José dos Pinhais, Paraná para eutanásia. A detecção sorológica da presença de anticorpos contra Leishmania sp. foi realizada por (ELISA) indireto e pela Reação de Imunofluorescência Indireta (RIFI). Além disso, impressão de linfonodo poplíteo coletadas ao acaso de 50 cáes com sinais clínicos suspeitos para leishmaniose visceral e analisados sob microscopia óptica para detecção de formas amastigotas, foram negativas. Amostras de soro de 364 animais foram testadas, e os resultados mostraram somente uma amostra positiva $(0,0027 \%)$, reagente ao ELISA e negativa à RIFI, entretanto, o cão não apresentava sinais clínicos. A vigilância ao acaso em uma população de vários locais de uma área metropolitana pode ser uma forma de prevenção da disseminação da doença. Com base nos resultados observados, Curitiba e região metropolitana foram consideradas de baixo risco para a leishmaniose visceral.

Palavras-chave: Leishmania sp., ELISA, RIFI, cão, zoonoses.

Leishmaniasis is caused by the protozoan species Leishmania, and is an endemic disease nationwide in Brazil except for the South region, where it has not been reported to date (JESUS; ARAUJO, 2007). Since there has been a significant increase of human and dog cases, active surveillance may be very useful to prevent it and maintain a disease-free status (JESUS; ARAUJO, 2007).

\footnotetext{
*Corresponding author: Marcelo Beltráo Molento

Departamento de Medicina Veterinária, Universidade Federal do Paraná - UFPR Rua dos Funcionários, 1540, CEP 80035-050, Juvevê, Curitiba - PR, Brasil e-mail: molento@ufpr.br
}

Dogs are reported the main reservoir of visceral leishmaniasis (DESJEUX, 2003), with its infection preceding human cases (MONTEIRO et al., 1994). Moreover, a positive correlation has been shown between the presence of infected dogs and new human cases in endemic regions (FALQUETO et al., 1986; OLIVEIRA NETO et al., 1988).

A total of 388,155 autochthonous cases of human visceral leishmaniasis were reported in Brazil from 1985 to 1999, showing demographic spread of the disease (REY, 2001). Although few human cases were reported in the past years, a total of 33 cases 
from 2007 to 2009, no autochthonous cases have been reported to date in the State of Paraná, southern Brazil (MINISTRY OF HEALTH, BRAZIL).

Although Paraná is free of canine visceral leishmaniasis (CVL), American tegumentary leishmaniasis (ATL) accounts for about $89 \%$ of the cases in the southern region, and there has been a gradual increase in cases, with the Northeastern area of Paraná being considered an endemic area of ATL (CASTRO et al., 2005; ZANZARINI et al., 2005; DUNAISKI, 2006; JESUS; ARAÚJO, 2007;).

Surveillance has not been performed in the most populated areas such as the state capital (Curitiba) and its surroundings. The purpose of the present study was to determine the seroprevalence of CVL in dogs sent at the Center for Zoonosis Control of São José dos Pinhais, in Paraná, before euthanasia.

The study was conducted in the city of Sáo José dos Pinhais $\left(25^{\circ} 32^{\prime} 05^{\prime \prime} \mathrm{S}\right.$ and $\left.49^{\circ} 12^{\prime} 23^{\prime \prime} \mathrm{W}\right)$ which is located in the metropolitan area of Curitiba. The city area is $946 \mathrm{~km}^{2}$ with a population of 263,622 inhabitants, demographic density of 276 inhabitants. $\mathrm{km}^{-2}$ and an altitude of $906 \mathrm{~m}$. It is characterized by humid subtropical climate with an average annual temperature of $16^{\circ} \mathrm{C}$. (IBGE, 2007).

The present study has been approved by the Animal Ethics Committee (protocol 022/2006) of the Sector of Agricultural Sciences at the Federal University of Paraná. From February 2006 to July 2007, a total of 364 blood samples were collected from at the Center for Zoonosis Control of São José dos Pinhais, Paraná.

A total of 364 dogs were physically restrained and anesthetized with ketamine chloride $\left(10 \mathrm{mg} \cdot \mathrm{kg}^{-1}\right)$ and xylazine chloride $\left(1 \mathrm{mg} \cdot \mathrm{kg}^{-1}\right)$ intramuscularly. Following this initial tranquilization procedure, $12.5 \mathrm{mg} \cdot \mathrm{kg}^{-1}$ of sodium thiopental was administered intravenously for blood sampling prior to euthanasia. Euthanasia was conducted by veterinarians of the Center for Zoonosis Control following the standard protocol and was not related to the present study. Whole blood samples were then collected by intracardiac punction, and serum samples were stored at $-20{ }^{\circ} \mathrm{C}$ in $1.5 \mathrm{Ml}$ Eppendorf tubes. A data file was created for each dog, including the day of the sampling, sex, size, age, breed and ownership status.

After euthanasia, the popliteal lymph nodes were also randomly collected from 50 dogs with suspected clinical signs of CVL including weight loss, skin lesions and enlarged lymph nodes. Lymph nodes were longitudinally excised and pre-dried with tissue paper, impressed on 3 slides (imprints) for each dog, and then stained using Romanowski method for direct parasite examination.

Indirect enzyme-linked immunosorbent assay (ELISA) and immunofluorescence antibody test (IFAT) were performed in dog serum samples to search for anti-Leishmania antibodies (MAIA, et al. 2007; METTLER et al. 2005). The samples were processed at the Zoonosis Laboratory of the School of Veterinary Medicine and Animal Science, São Paulo, State University, UNESP, Botucatu campus, São Paulo, Brazil.

The study population comprised 218 males (59.9\%) and 146 females (40.1\%). Of all, 157 were large (43.1\%), 135 medium (37.1\%) and 72 small-sized dogs (19.8\%) and 23 (6.3\%) were puppies (0-12 months old), 327 (89.8\%) were adults (1-8 years old), and $14(3.8 \%)$ were old dogs (9-15 years old). In addition, $36.8 \%$ were pure breed dogs and $63.2 \%$ were mongrel dogs; 142 dogs were owned (39.0\%) and 222 were stray (61.0\%) dogs.

All serum samples tested were negative in both ELISA and IFAT, except for one sample that was positive by ELISA $(0.0027 \%)$, but was negative by IFAT. The ELISA positive sample was from a male adult, large-sized, stray mongrel dog that came from the district of Afonso Pena.

No amastigote forms of Leishmania were seen in the imprints of the popliteal lymph nodes.

Large dogs were the most prevalent in the study, probably because they are guard dogs for home/property. These dogs live mostly outdoors and may be more exposed to mosquito bites, as previously reported throughout South America (DANTAS-TORRES, 2009). Therefore, an active surveillance of owned dogs should be conducted especially on adult large dogs living mostly outdoors.

As there were no parasite-positive dogs among the symptomatic ones in the present study, clinical screening based on enlarged lymph nodes, alopecia, anorexia, and weigh loss may not be sensitive for CVL surveillance in non-endemic areas, as reportedly for endemic areas (SLAPPENDEL, 1988; CIARAMELLA et al., 1997; KOUTINAS et al., 1999; QUEIROZ et al. 2006). Moreover, only one seropositive sample was from an asymptomatic dog, showing that active surveillance should be carried out in a representative sample as well as randomly selected individuals.

The assessment of leishmaniasis status in a random population of dogs from different site other than a non-endemic area allowed the active surveillance of potential disease focuses. Dogs are interesting sentinels for leishmaniasis based on the likely correlation between presence of infected dogs and new human cases in an endemic region (FALQUETO et al. 1986). Besides, dog infection precedes human cases (FALQUETO et al. 1986 and OLIVEIRA NETO et al. 1988).

Dogs are considered the main reservoir of CVL (MONTEIRO et al. 1994; DESJEUX, 2003). Therefore, active surveillance of canine leishmaniasis should be consistently carried out using the Center for Zoonosis Control as a major source for dog sampling.

This study reported the first seroprevalence data of CVL in the city of Curitiba. Disease distribution in a dog population and factors that determine this distribution are vital observations in an epidemiological retrospective analysis of this disease in this region. Although we have found a very low serum prevalence in the dogs studied, surveillance is crucial since the vector may cross natural geographical barriers and carry the infectious agent into new regions, and dog cases will appear before human cases.

\section{References}

BRASIL. Ministério da Saúde. Secretaria de Vigilância em Saúde. Departamento de Vigilância Epidemiológica. Manual de Vigilância e Controle da Leishmaniose Visceral. Brasília, 2006. Série A. Normas e Manuais Técnicos.

CASTRO, E. A. et al. Eco-epidemiological survey of Leishmania (Viannia) braziliensis American cutaneous and mucocutaneous leishmaniasis in Ribeira Valley River, Parana State, Brazil. Acta Tropica, v. 93, n. 2, p. 141-49, 2005. 
CIARAMELLA, P. et al. A retrospective clinical study of canine leishmaniasis in 150 dogs naturally infected with L. infantum. Veterinary Record, v. 141, n. 21, p. 539-543, 1997.

DANTAS-TORRES, F. Canine leishmaniosis in South America. Parasites \& Vectors, v. 2, n. suppl. 1, p. S1, 2009.

DESJEUX, P. Leishmaniasis. Journal of the Annals of Tropical Medicine Parasitology, v. 97, n. 1, p. 3-15, 2003.

DUNAISKI, M. Epidemiologia da Leishmaniose tegumentar americana na regiáo do Vale do Ribeira, Paraná: cães reservatórios ou hospedeiros acidentais? 2006. 56 p. Dissertação (Mestrado em Ciências Veterinárias) - Universidade Federal do Paraná - UFPR, Curitiba.

FALQUETO, A. et al. Participação do cão no ciclo de transmissão da leishmaniose tegumentar no município de Viana, Estado do Espírito Santo. Memórias do Instituto Oswaldo Cruz, v. 81, n. 2, p. 155-163, 1986.

INSTITUTO BRASILEIRO DE GEOGRAFIA E ESTATÍSTICA IBGE. Sáo José dos Pinhais. Rio de Janeiro, 2007. Disponível em: <http://www.ibge.gov.br>. Acesso em 24 de fevereiro de 2007.

JESUS, J. R.; ARAÚJO, F. A. P. Leishmaniose tegumentar americana: uma visão da epidemiologia da doença na Região Sul. Clínica Veterinária, v. 12, n. 71, p. 82-84, 2007.

KOUTINAS, A. F. et al. Clinical consideration on canine leishmaniasis in Greece: a retrospective study of 158 cases (1989-1996). Journal of the American Animal Hospital Association, v. 35, n. 5, p. 376-383, 1999.

MAIA, C. et al. Diagnosis of canine leishmaniasis: conventional and molecular techniques using different tissues. The Veterinary Journal, v. 179, n. 1, p. 142-144, 2007.

METTLER, M. et al. Evaluation of enzyme-linked immunosorbent assays, an immunofluorescent-antibody test, and two rapid tests (immunochromatographic-dipstick and gel test) for serological diagnosis of symptomatic and asymptomatic Leishmania infections in dogs. Journal of Clinical Microbiology, v. 43, n. 11, p. 5515-5519, 2005.

MONTEIRO, P. S.; LACERDA, M. M.; ARIAS, J. R. Controle da leishmaniose no Brasil. Revista da Sociedade Brasileira de Medicina Tropical, v. 27, n. 3, p. 67-72, 1994.

OLIVEIRA-NETO, M. M. et al. Outbreak of american cutaneous leishmaniasis in a periurban area of Rio de Janeiro city, Brazil. Memórias do Instituto Oswaldo Cruz, v. 83, p. 427-435, 1988.

REY, L. O complexo "Leishmania donovani" e a leishmaníase visceral. In: _. Parasitologia. 3 ed. Rio de Janeiro: Guanabara Koogan, 2001. p. 253-266.

SLAPPENDEL, R. J. Canine leishmaniasis: a review based on 95 cases. Veterinary Quarterly, v. 10, n. 1, p. 1-16, 1988.

ZANZARINI, P. D. et al. Leishmaniose tegumentar americana canina em municípios do norte do Estado do Paraná, Brasil. Caderno de Saúde Pública, v. 21, n. 6, p. 1-4, 2005. 